HUBERT KASZYŃSKI

ORCID 0000-0001-5714-6842

Olga MaciejeWSKa

ORCID 0000-0001-9371-3197

Uniwersytet Jagiellonski

w Krakowie

\title{
HARM. RESPONSIBILITY. AWAKENING. REMEMBRANCE OF THE KRAKOW GHETTO AND KL PLASZOW
}

\begin{abstract}
AвstRact. Kaszyński Hubert, Maciejewska Olga, Harm. Responsibility. Awakening. Remembrance of the Krakow Ghetto and KL Plaszow [Niebezpieczeństwo. Odpowiedzialność. Przebudzenie. Wspomnienia z getta w Krakowie i z KL Płaszów]. Studia Edukacyjne nr 59, 2020, Poznań 2020, pp. 133-149. Adam Mickiewicz University Press. ISSN 1233-6688. DOI: 10.14746/se.2020.59.10
\end{abstract}

The aim of the article is to present the issue of educational work carried out in a spirit of axiological education in the former Krakow ghetto and the former labor and concentration camp Plaszow in Kraków. The significance of the activities consists of the acquisition of knowledge about the difficult local history of the Holocaust and its heritage by confrontation with the ghetto and the former camp and relics of the past. The key area for dealing with the issues of harm, responsibility and awakening is social work, which in its axiological aspect largely focuses on reflection on the theory and practice relating to the complex issue of responsibility. These activities not only stimulate the historical awareness of totalitarianisms and the memory of them in the social and moral dimension, but also and most importantly they are a precondition for the mental health and moral development of a person, family, group, and social community.

Key words: social work, axiological education, remembrance, KL Plaszow, mental health

\section{The nature of social work}

Social work in its axiological dimension is largely focused on reflection on theory and practice referring to the complex issue of responsibility. One can tackle this question in perhaps the most synthetic way by asking two fundamental ethical questions: What is my responsibility for the harm you have 
faced on my account? And What is your responsibility for true forgiveness, meaning that of unforgivable harm? Striving to build a relationship with the Other, founded upon openness to accepting the experience of hurt, as well as upon emotional complementation, is an essential condition of the moral growth of a person, family, group and social community. And yet there is a lack of simple and effective working methods available to the architects responsible for deconstructing the axiological spaces in which we describe destructions as profound or complete breaks to the continuity of previous experience and disintegration of the objectives and means used to reach them. It is also important to emphasise that even if such methods were available, the possibility of applying them would probably depend not so much on their skills in putting them into practice as on eliciting the specific arts required for the professional.

\section{The (im)possibility of forgiveness}

The Holocaust is an important part of twentieth-century European history - and at the same time of the histories of individual national communities and states. Remembrance of the tragic events and the people they affected has been shaped and (not) maintained in various ways, depending on their location and developmental circumstances. When discussing the models of memory of Annihilation, one cannot fail to mention that they are also reflected in education systems. Education about Holocaust is a space for reflection in the discipline of many humanities and social sciences (e.g. pedagogy, sociology, history), as well as a number of practical activities. Of course, it presupposes specific goals and effects related to both the theoretical aspect (building knowledge about the past) and the axiological space related to building the world of values, shaping the desired attitudes, such as tolerance and openness, opposition to discrimination, racism and xenophobia. It should be emphasized at this point that the education systems themselves in this area to a large extent reflect the models of memory about the Holocaust in given communities. Undoubtedly, for Europe it remains a unique experience, which has become something of a point of reference for the formation of a system of values and norms regarded as binding. This system points to the need for constant vigilance and sensitivity to the resurgence of nationalist and authoritarian moods, and the danger of groups and communities becoming seized by ideologies conducive to divisions, harm, and non-recognition.

Educational work on the issues of intra- and international trauma associated with the experiences of war should not just aspire to deal with a nation's own often painful past. It should also, and perhaps above all, seek to understand other perspectives, undertake a dialogue, and finally lead to reflection 
on the universal dimension of this experience. It is also obvious that education on the Holocaust has a moral dimension, and is inextricably linked to teaching of values.

When learning about the Holocaust, it is important to discern not only the usual Baumanian co-occurrence of ordinary social facts, but also the broader domination of the eugenic cultural context, which by allowing industrial atrocity, also precluded its forgiveness. According to Hannah Arendt's interpretations, ${ }^{1}$ the evil of eugenic murder became banal, turning into a bureaucratic, objectified and faceless procedure. Even if the evil were personified and had the name of a specific perpetrator who was accused, proven guilty and punished, that person would not feel either a sense of guilt or contrition. And it does not matter whether we interpret this state of affairs by considering the internationalisation of the culture of "times of desecration", or even as an atavistic need to disavow actions in the light of the sheer mass of evil that a human as a moral being cannot bear. In any case, a perpetrator feeling no guilt, and thus incapable of repentance, extinguishes any potential forgiveness. "Potential" is the operative word here, as it bears the possibility of disintegration of the identity of the victim, for whom retaining the sense of harm and the need for revenge might be the only foothold guaranteeing survival. Forgiving the unforgivable becomes even more illusory. For the victims, therefore, the anticipated justice that is almost suspended in a void, and of which a sine qua non condition is to affect the perpetrator, as well as the possibility of forgiveness, become an experience of repeated damage. The only path of compensation on the horizon is to undertaken the painful work on deconstructing the cultural scripts blocking contrition, as well as, more importantly, on trauma in its social dimension. This entails jointly diagnosing and defining collective traumatic experiences.

Jeffrey Alexander's work ${ }^{2}$ shows us that social work in trauma designed to enrich collective identity does not result from the nature of the suffering itself. On the contrary, it is connected to cultural determinants which enable or block the emergence of influential groups bearing witness to trauma. These groups possess the resources, authority and interpretive competences to efficiently propagate the demand to the right for the trauma to be acknowledged. This perspective, which considers the presence and contribution of the second generation, opens the possibility of leaving the foundations of work on forgiveness in the legacy. Socially defined trauma makes it possible not only to understand perpetrators' guilt ("how could a person do this?"), but also to take responsibility for the harm done "(these were

\footnotetext{
${ }^{1} \mathrm{H}$. Arendt, Eichmann in Jerusalem. A Report on the Banality of Evil, 2006.

2 J. Alexander, Znaczenia społeczne, transl. S. Burdziej, J. Gądecki, Kraków 2010, p. 195-221.
} 
members of my family, neighbours, the community I live in"). This means activating transgenerational experience of the sense of guilt, expressing remorse and asking for forgiveness. Yet this process is again in danger of being interrupted, because those who could forgive are absent. The only path that those requesting forgiveness can follow is to search - in the symbolic space of collective identity - personified objects of the harmed individuals. Communing with them can be compared to identifying - to paraphrase George Herbert Mead's concept - with the "absent significant other". Still, though, closure of the transgenerational process comes with the pardoning experienced in a direct relationship with the descendants of survivors, who are willing to work to distinguish the evil dealt to them from the people who perpetrated it. Forgiveness of harm inflicted at the limit, however, demands passage of time, a changed perspective and moral developmental tasks undertaken in an intergenerational process.

The first generation was characterised by the experience of silence on unspeakable harm as well as moral transgressions. This generation was saddled with a kind of mission to pass life on, "although its members were emotionally impenetrable to their loved ones". ${ }^{3}$ An inherent element of their biographies was silence, often as their only available means of expression of their own experiences and the Holocaust. The second generation lived in the shadow of responsibility for the memory and the numerous coinciding ways of grasping past events. At the same time, they were aware of the enormous burden their parents bore and their mental fragility, and thus did not ask about their lost ancestors, in keeping with the unspoken rule imposing silence in response to the traumatic way in which they were killed. And finally, the third generation is the one with the right and responsibility to learn through drawing on the emotional experience of survivors as a common heritage of an inhuman time. Its duty is to work on forgiveness.

\section{Mental health and its correlates}

The transgenerational way of thinking about transcending trauma is inspired by an article by Richard Kearney ${ }^{4}$ on possible and impossible forgiveness at the limit, discussing the conceptions of Paul Ricœur. The philosophical reflection in this paper is saturated with potential for application among social

${ }^{3}$ B. Janusz, Niewypowiedziane cierpienia. Międzypokoleniowy przekaz traumy, Miesięcznik Znak, 2015, 720; http:/ / www.miesiecznik.znak.com.pl/7202015bernadetta-januszniewypowiedziane-cierpienia-miedzypokoleniowy-przekaz-traumy/, [access: 2.09.2018].

${ }^{4}$ R. Kearney, Wybaczanie graniczne: możliwe, czy niemożliwe?, transl. M. Pancewicz-Puchalska, Studia Pfilosophica Wratislaviensia, 2010, 3, p. 11-24. 
workers, who are concerned not only with the skills of social diagnosis of the harm experienced by people, groups or communities, but also the therapeutic possibilities of shaping mental health. In contemporary social sciences, mental health is regarded as normal functioning in spite of relatively unfavourable conditions of life and development, traumatic events and the adversities of date. It is aspiring to a kind of "awakening", a fortifying state involving transformation of harm experienced at the emotional and spiritual level. Yet the possibility of turning harm into developmental potential demands moral work on responsibility and pardoning.

The way of thinking about intergenerational forgiveness outlined here is a starting point for trying to answer the question of how we can accompany injured parties more consciously and empathically. Let us again emphasise that the crucial matter is the ability to symbolically take responsibility for the harm inflicted upon others and seek the opportunity to open a dialogue on forgiveness with them. Responsibility is a value that is not intrinsic to the human being or assigned by the very fact of being born a human, but at a certain point in life becomes a significant element determining the foundation, construction and sustaining of relations with the Other. It is also significant here that one experiences responsibility. One is therefore not only conscious of it, but the fact of bearing it must be clearly marked on one's everyday life. It is important to look at responsibility not as a sort of state or appurtenant norm of action, but as a dynamic process of expanding the realms of responsibility, and thus encompassing further, new areas of life as well as refining the responsibility for the key areas for the development of one's potentiality. ${ }^{5}$

The dialogue of forgiveness, founded on responsibility, concerns the reconstruction of microhistories of refusal to recognise the humanity of a person endowed with irremovable dignity and with the right to love, standing in an "I-You" dyad, to cite the work of Axel Honneth. ${ }^{6}$ Non-recognition - meaning questioning a person or community's dignity and refusing them the right to love and relationships with others - becomes harm, the consequences of which can be diagnosed as post-traumatic stress. Without getting into the plethora of empirical research undertaken in the fields of psychiatry and clinical psychology, we should emphasise that the appearance of the symptoms fulfilling the diagnostic criteria of this disorder is moderated by genetic and psychological predispositions as well as social factors - generally defined as social support.

${ }^{5}$ K. Ablewicz, Pola odpowiedzialności dorosłego i dziecka. Tradycja, ponowoczesność $i$ co dalej..., Miesięcznik Znak, 2007, 625; http://www.miesiecznik.znak.com.pl/6252007krystyna-ablewiczpola-odpowiedzialnosci-doroslego-i-dziecka-tradycja-ponowoczesnosc-i-co-dalej/, [access: 1.09.2018].

${ }^{6}$ A. Honneth, The Struggle for Recognition: The Moral Grammar of Social Conflicts, transl. J. Anderson, 1st MIT Press edition, 1996. 
From the perspective of social work, the challenge is to strengthen such forms of social support, expressed by dialogic competencies concerning work on the triadic experience of "harm, responsibility and forgiveness".

\section{A metaphysical void as a form of commemorating the atrocity of KL Plaszow}

A symbolic university which does not so much effectively teach responsibility as reveal the difficulty of forgiveness, reforming broken relationships and undertaking dialogue is the area of the former KL Plaszow concentration camp. The value of this site lies in the fact that its remembrance is an extremely complex issue, as Josef Bau perceptively recognised when writing:

To talk about the Plaszow concentration camp is like taking on an impossible task: building a skyscraper with one's own hands containing an archive of the atrocities inflicted on the Jewish nation. ${ }^{7}$

Even today, the space of the former Nazi German work and concentration camp (without detracting from the engagement of the people and institutions and the unquestionable value of the results of their work) is a "non-place", both familiar and alien, friendly and hostile, and above all with a startling contradiction between its recreational function and that of commemorating the dead and murdered. Perhaps the power of this tension, practically constantly noticeable for more than 70 years, lies not only in the specific content of discussion of visual forms of remembrance, but especially in the palpable duty of education on the causes of this state of affairs.

The Polish researcher of the culture of remembrance, Roma Sendyka, develops in her research the concept of "non-place of memory", referring directly to KL Plaszow gives it as an example of this type of space. The cited author defines non-places of memory as scattered locations of various acts of extermination or genocide that took place in the last century - this specific border is marked by the extremely important category of "living memory" associated with the presence of witnesses to events. As he emphasizes

These places do not have characteristic physical features: they can be extensive or point-like, located in a city or in a forest clearing; they are usually accompanied by a kind of physical mixing of organic (human remains, plants, animals) and inorganic (ruins, new buildings) orders. ${ }^{8}$

\footnotetext{
7 J. Bau, Czas zbezczeszczenia, Kraków 2006.

${ }^{8}$ R. Sendyka, Miejsca, które strasza (afekty i nie-miejsca pamięci), Teksty Drugie: teoria literatury, krytyka, interpretacja, 2014, 1(145), p. 85.
} 
The main feature that connects non-place of memory as understood by Romy Sendyka is the fact that this space is an inconvenient issue for the surrounding community, and its commemoration appears to be a significant threat to collective identity, therefore it is easier (although also criticized) for the local community not to commemorate. The tension outlined above is present and strongly felt in the space of the former KL Plaszow, which makes it the subject of our particular research and educational interest.

Events directly related to the functioning of KL Plaszow (in the years 1942-1945) $)^{9}$ and those overwritten for a number of subsequent years were transformed into a specific heritage. It is not something indisputable, but only precious and bringing pride to the community. Sometimes it is a source of anxiety about the past, sometimes it is questioned because it is in contradiction with the group identity and the directions of its formation. Therefore, we can undoubtedly, following Sharon Mcdonald, define the heritage of Płaszów as "difficult". ${ }^{10}$ Its significance can be reduced to the constant readiness in the tissue of society to update social divisions, antagonisms and conflicts. A difficult legacy is disturbing and awkward for the community. Its celebration is never without ambiguity, on the contrary - it usually becomes a source of dilemmas related to an acceptable public representation of past events and the symbolism assigned to them. Often in such situations, maintaining the coherence of the community requires "not-remembering", displacing to the social unconscious what is impossible to reveal for social identity.

Not remembering and avoiding certain topics, questions and answers is obviously not a universal method of dealing with the problem and conflict that may arise around the perception and treatment of the history of a given community and the space in which it lives. The domination of the mechanism of tabooing selected issues may lead to the reduction of social facts that build the identity of the community, giving it multiple sources of a sense of continuity and durability. It may also cause the weakening of its culture-forming resources related to, inter alia, the possibility of adapting the complexity, diversity and ambiguity of one's own history. Not without significance is also the loss of the moral potential of community growth, for which the necessary condition is the ability to bear responsibility for the past, and thus exceed the narcissistic image of the uniqueness of the social group to which one belongs.

${ }^{9}$ See: T. Wroński, Obóz w Płaszowie - miejsce masowej eksterminacji ludności żydowskiej, polskiej i innych narodowości w latach 1942-1945, Warszawa 1981; A. Bieberstein, Zagłada Żydów w Krakowie, Kraków 1986; R. Kiełkowski, Obóz koncentracyjny w Płaszowie, [in:] Zlikwidować na miejscu, Kraków 1981.

${ }^{10}$ S. Macdonald, Difficult heritage, Negotiating the Nazi Past in Nuremberg and Beyond, London 2009, p. 1. 
However, in every community there comes a moment when the need to confront the past is revived, which is not to lead to settlements, arouse trau$\mathrm{ma}$, but to understand the specificity of one's own fate. Reaching and working through a difficult heritage strengthens the development potential of a community, which is associated with a sense of its historical continuity and permanence, the ability to adapt differences and responsibility for past actions. Paul Ricoeur describes those situations that lead to confrontation with a difficult past, using certain psychoanalytical terms such as "repression", "unarticulated trauma", "shameful trauma" that require working through. ${ }^{11}$ This process can take various forms, ranging from research studies to various manifestations of didactic and educational activity. One of the forms of work is axiological education. We clearly emphasize that we perceive the subject of the specificity of the former KL Plaszow camp in the context of the community and the space of difficult heritage as a specific duty of socially oriented therapists whose activities are in the area of clinical sociology and social work. Its essence is contained in the words of Marian Golka:

Social memory is based on the fact that the generations of children, grandchildren, great-grandchildren and still further social heirs have a sense of some continuity with the generations of their predecessors - and thus a sense of continuation of fate, a sense of identity and responsibility for the past and future. Memory is a consensus over time - a consensus that is difficult to form, breaks easily, and even more difficult to repair. Social memory creates a social order, but also its durability depends on this order. Order changes, so does memory. ${ }^{12}$

People interested in the subject of "our" camp are well aware that what makes it unique is its organic ties with Krakow and its residents. The camp grew out of the city's urban fabric and the Krakow ghetto, and became a functionally, personally and emotionally connected part of our collective space. Regardless of the attitude of those living nearby - be it heroic, compassionate, indifferent, hostile or hateful - the first and last act of the annihilation of the Cracovian Jews was played out in our neighbourhood, where the curtain was always open. A frequently accentuated condition of the murder was the gradual separation of the degenerate tissue of "non-persons" from the healthy social tissue. The history of the Krakow camp seems to be a departure from this rule. Though strained, ties were never completely broken, and yet a quarter of citizens were murdered or sent away to their deaths. Does this not make the scale of our responsibility even greater? Is it not too huge to be recalled? Not to mention the quest for forms of commemoration of our responsibility and the possibility of forgiveness. The momentousness of this place is connected

\footnotetext{
${ }^{11}$ P. Ricoeur, Pamięć, historia, zapomnienie, transl. J. Margański, Kraków 2006.

${ }_{12}$ M. Golka, Pamięć społeczna i jej implant, Warszawa 2009, p. 8.
} 
to a metaphysical void symbolising a break in the continuity of human fate and the possibility of dialogue that is the foundation of humanity. This is the crux of Plaszow's invisible remembrance in a truly open university accessed by the will, commitment and effort to create one's own curriculum.

Sites of memory at former Nazi work and concentration camps have three main functions in the contemporary world. ${ }^{13}$ Above all, they are places where one encounters history directly. Secondly, they are sites at which "one comes up against into a certain authenticism" - which fundamentally distinguishes them from museums, both traditional and modern. Finally, they are also spaces of remembrance. With time, influenced by changes in the discourse on history and the Holocaust and the development of the education system, the proportions of the significance attached to specific functions have also changed. It is important to note that "a site of memory is a silent and eloquent witness as well as a tool that helps the next generations to preserve the memory". ${ }^{14}$ What sets the KL Plaszow site apart, and affects the knowledge of its unique history, is the difficulty with deciphering the space. It remains inextricably linked to the continually pertinent question of the permissible and desirable forms of remembrance, the extent of interference in the space, and the way of talking about and remembering the things whose traces are barely noticeable today.

Using methods of so-called axiological education, which assumes emotional empathy and direct contact with a space marked by difficult experience, seems to be the element that could both make it possible to preserve the authenticity of the site and prevent it from being forgotten, while also facilitating an open discussion in the spirit of understanding and forgiveness.

\section{Axiological education on the site of the former KL Plaszow camp}

Modern education, responding to the challenges of the contemporary world, should be based mainly on the student-oriented model, which is characterized by the domination of learning over teaching. A young person becomes to a large extent an independent subject of the education process - co-responsible for its quality, course and effects. Shifting attention from teaching to real activity, while departing from unambiguous and formalized paths of behaviour (towards) young people, opens up completely new possibilities. The answer to the outlined needs seems to be the implementation and

${ }_{13}$ P.M.A. Cywiński, Europejskie miejsca pamięci. Refleksje, [in:] Płaszów. Odkrywanie, Kraków 2016, p. 13.

${ }^{14}$ Ibidem, p. 28. 
use of methods based on the assumptions of axiological education. The basis for the implementation of activities focused on the development and awakening sensitivity to the Other and his history should be a model of a joint study of the values that are "the core of our existence and the source of an authentic and reasonably justified sense of life".${ }^{15}$ It is based on the idea of discovering yourself and your way of seeing the world together. It is often necessary to reveal one's individual experiences, experiences (including difficult ones), and share your emotions with others - all in a safe atmosphere of a small group. The aim of axiological education projects must be to create a space for a group experience of values. As Edmund Husserl pointed out, "there is no cognition without experience".

We define axiological education as leading others - with constant attentive and empathetic accompaniment - in the direction determined by universal values that are significant for a given cultural circle and the community living in it. The implementation of the assumptions of this form of activity includes continuous training in humans of the ability to identify / recognize and name values, understand them, prioritize, and implement them every day, but also the ability to pass them on to others. We emphasize that in this spirit of education, the search for working methods that fit in with the postulates of personalistic philosophy is of particular importance. Its main goal is to acquire the competence to achieve axiological maturity, and thus to prepare for independent and conscious existence in the world of values, and to move in it responsibly. ${ }^{16}$ It includes activities based on the activity of a person and their environment, aimed at shaping the human personality - in the rational, emotional, spiritual sphere - so that he is capable of realizing values.

The close to us understanding of axiological education, which we implement in the spaces of difficult heritage and places marked by the painful past of harm and non-recognition, can be defined by recalling its five basic aspects:

1. The essence of education is an intellectual and emotional confrontation of oneself and of the participants in the education process with values - the buttress of individual and collective social life.

2. In order for axiological education to exist and fulfill its assumptions, it must take place in a space that is safe for its participants, an atmosphere conducive to open exchange of thoughts.

${ }^{15}$ A. Siemianowski, Wartości i sens życia z punktu widzenia ontologicznego, [in:] Wartości dla życia, Ed. K. Popielski, Lublin 2008.

${ }^{16}$ We write about axiological education inter alia in: K. Rożniatowska, H. Kaszyński, O. Maciejewska, Ksztatcenie do pracy socjalnej w świetle ewaluacji Spaceru Aksjologicznego w Kobierzynie, Praca Socjalna, 2019, 3(34), p. 75-92. See also: K. Olbrycht, Wychowanie do wartości - w centrum aksjologicznych dylematów wspótczesnej edukacji, Paedagogia Christiana, 2012, 1(29), p. 89-104. 
3. The foundation of education is an emotional act. It is based not so strong on the transfer of knowledge, but on the emotional actualization of existential values - meeting them, fleeting impressions, attempts to define and interpret what becomes the subject of education.

4. Work in the spirit of axiological education is based on a dialogue with coexperiences - it never takes place in an oblique relationship between the educator-subject - participant-object.

5. The aim of axiological education is to stimulate reflection and self-reflection as well as work with one's own emotions and reactions.

The focus of axiological educational work is to inculcate understanding and a sense of values as well as the ability to realise them in the social space. It entails undertaking an open discussion on the transgenerational transmission of a microhistory and empathising with it. Axiological education is a process of emotional restitution of social microspaces that is an essential condition for the resurrection of reflection on inherited responsibility for harm.

At the Institute of Sociology of the Jagiellonian University in Krakow, a particularly important role in the education of students of sociology and social work is played by the search for working methods that implement the proposals of personalistic philosophy. The collective work refers not only to contemporary social issues, but also to their historical determinants. An extremely important subject in certain classes is reflection on the history of twentieth-century eugenics, and especially its local context. After all, without understanding and studying the times in which "history was derailed", it is hard to fully comprehend the social responsibility for people particularly susceptible to injury and exposed to social non-recognition and harm. The particular foundation of these initiatives is axiological education, which in its simplest terms can be defined as guiding individuals in a direction determined by values. ${ }^{17}$ Its objective is to prepare a person for independent, responsible and fully conscious functioning in the world of values, and thus attaining a state of a certain axiological maturity. These educational activities should not only equip the people in question with the ability to identify, recognise and understand values, but more importantly awaken self-reflection and the desire to know oneself in them, and form the ability to confront their own emotions.

We make the idea of axiological education a part of the assumptions of the pedagogy of remembrance, also known as memorial site pedagogy. On the theoretical level, it alludes to the theses of Theodor W. Adorno, who, in the context of a moral settlement with the legacy of Nazism, emphasized

17 P. Kołodziński, Myśli o edukacji aksjologicznej, lo2.szczecin.pl/publikacje/pawel/09.doc, [access: 31.08.2018]. See also: P. Duchliński, G. Hołub (eds.), Oblicza doświadczenia aksjologicznego. Studia i rozprawy, Kraków 2011. 
the fundamental importance of educating a self-critical, autonomous and non-conformist personality. ${ }^{18}$ The starting point for the concept of the pedagogy of remembrance was the postulate "that Auschwitz should not be repeated again" ${ }^{19}$ Its foundation is the assumption that two factors should be used in pedagogical and didactic processes: the perception of an authentic historical site (in this case the former KL Plaszow) and reflection on the memory of the past. Nowadays, it becomes an element of a wider educational process, the aim of which is to educate active, creative, conscious attitudes towards threats to the modern world, such as violations of human rights, threats to democracy, xenophobia.

A certain area, natural for the outlined context, on which we base the assumptions of the implemented activities, is also the pedagogy of place understood as the theoretical perspective of educational research, which describes the dialectical relationship between man - place, man - space. This relationship becomes crucial for learning and teaching processes. No less important is its importance for the formation of human identities and for the (re) construction of social relationships. The theoretical framework of place pedagogy is complex, and perspectives for analyzing it vary depending on the discipline or research approach. According to Maria Mendel, ${ }^{20}$ the pedagogy of place, considered in the category of socially engaged research, recognizes learning as a change that always takes place in a specific place. The key questions for her are, firstly, questions about the teaching potential of a given place, the specificity and value of learning "in" the place, "from" the place and secondly, projects of educational and social activities carried out in particularly "sensitive" places.

In the Department of Applied Sociology and Social Work at the Jagiellonian University's Institute of Sociology we employ rather unconventional methods, undertaking initiatives based upon the idea of including students, middle- and high-school pupils, the local community, practitioners and professionals in the academic education process. We carry out various activities targeted at organising projects of a local nature in an environment to some extent "branded" by history. In the 2017/2018 academic year, we worked with pupils from High School no. XLIII in Krakow. This school is unique in that one of the last remaining fragments of the Krakow ghetto wall has become an integral part of everyday life there. The framework for the activity of the students, school pupils and their teachers participating in the

18 T.W. Adorno, Erziehung zur Mündigkeit, Frankfurt 1970, p. 92.

19 T.W. Adorno, Wychowanie po Oświęcimiu, Miesięcznik Znak, 1978, 285(3), p. 47.

${ }^{20}$ See: M. Mendel (ed.), Pedagogika miejsca, Wrocław 2006; K. Maliszewski, Pedagogicznie mieszka człowiek, [in:] Pedagogika na pograniczu światów. Eseje z cyklu "Medium Mundi", Katowice 2015. 
project was a pair of courses titled "Issues of Twentieth-Century Eugenics" and "Memory - Identity - Trauma". This encompasses several key areas: 1) learning about the idea of eugenics: its sources, the sociohistorical circumstances in which it emerged and developed, allusions in the actions of the Nazis prior to and during the Second World War, 2) introduction to the history of extermination of groups deemed not worthy of life in the Second World War, 3) group experience of the planning, design and implementation of educational initiatives focused on the history of the Krakow ghetto and KL Plaszow, 4) critical reflection and discussion on the presence of the idea of eugenics in the contemporary world and questions of the intergenerational transmission of trauma and experience of causing harm, 5) debate on the responsibility of contemporaries for those experiencing damage and non-recognition, as well as for memory.

The course participants incorporated into the transgenerational process not so much knowledge as the emotional state provoked by learning about this specific part of Krakow's history. One of the original results of the students' work was drawing up a wartime journal written from the perspective of child living in Krakow, marked by the experience of harm. The main source of the originality of this work was that each entry resulted from the students' empathising with the specific details of those days, the emotions and thoughts that people might have had in confrontation with the unknown and "other". Careful reading of a journal demonstrates the sensitivity of its authors. This was complemented by the production of photographical documentation of the site of the former ghetto. Each photograph became a point of departure for an individual narrative.

It is obvious that exclusively historical knowledge, even at the highest level and stemming from a genuine desire to explore it, is insufficient for creating such a project. Here we might again cite axiological education, the medium of which might be a person with an experience of harm, works referring to that person or produced by him or her, as well as an array of transitory micronarratives transmitted orally, present in the educational space. Their power lies in the capacity to activate in recipients individual experiences, feelings, emotions and desires, reflected by the truths derived from the wisdom of survivors which above all serve to encourage the effort to make changes to oneself and understand the surrounding world.

An important focal point of the course was the joint workshop bringing together students and high-school pupils on the 75th anniversary of the liquidation of the Krakow ghetto - 13 and 14 March 2018. The discussion at the workshop was founded on the general premise that the symbolism of the meanings of the Krakow ghetto and the former KL Plaszow work and concentration camp is linked to the possibility of human transcendence of the experi- 
ence of harm as well as openness to the future and development. The watchword upon which the work of the school pupils and their teachers was based was "Jews in Krakow and the Krakow ghetto - I know, I feel, I want to feel, I want to find out". The presentations, exchanges of ideas, and co-presence were imbued with the naturalness of dialogue on questions that were difficult and ostensibly distant from the teenagers. There was a visible desire to create an open space for discussion, exchange of views, learning and gaining knowledge outside of official textbooks, and ultimately a strong manifestation of the right to search for knowledge and for an individual understanding and perception of history. The students and school pupils shared their own reflections concerning the history of the Nazi crimes committed in Krakow - their city, the experience of trauma and fear, the contemporary understanding of the harm inflicted many years ago, responsibility to the victims, and the right to talk about events with no single interpretation. The reflection on issues of destruction of "life not worthy of living" was a unique form of education that referred more to the emotional capacities of acquiring knowledge than to objectified fact-based communication.

The closing stage of the educational work was a meeting between the university students and school pupils and Pnina Ron of the University of Haifa, a professor at the department of social work involved in research on intergenerational inheritance of trauma, whose teaching is based in part on the personal experiences of belonging to the second generation of survivors. Particular attention was given to the importance of everyday, direct contacts in the process of transferring harm, but also implementing therapy, founded on care for the individual "here and now", since these are the sources of a certain knowledge of past (or not?) experience. The discussion also encompassed reflection on the particularly complex issue of transcending harm - not only by those who experienced, but also by the perpetrators - i.e. the need to focus on the descendants of those who caused the harm, intentionally or otherwise. The meeting therefore allowed the participants not only to increase their understanding of the issues of intergenerational transfer of damage, but also to search for possibilities for their presence in dialogue on responsibility and forgiveness.

\section{Conclusion}

We can trace the answer to the question about the educational obligation of interest in issues of eugenics, Nazi atrocities, the Holocaust, intergenerational transmission of damage and the responsibility for it to the problem of 
the increasing incidence of psychological disorders in contemporary societies. One of the sources of this trend is late modernity, as described by Zygmunt Bauman, as it boils down to the universal experience of the specific trauma resulting from permanent uncertainty and anxiety associated with the need to adapt to new life situations that often exceed individuals' resources for coping with stress and potential for adaptation. This results in a series of complex - and often difficult to characterise - phenomena described as identity disorders, disorganisation of the ego, or, finally, mental illnesses.

No less significant are the reasons resulting from macrosocial analyses referring the experience of the Holocaust to the realities of the contemporary world: the trauma associated with the phenomenon of migration, refugees and constant sources of violence, structurally embedded in global political and economic practices, in the Middle East and African states. Social workers should be prepared to meet non-obvious future challenges concerning practice, learning - from the Holocaust - to recognise nationalistic moods and manifestations of xenophobia.

The activities presented in this article, carried out in the space of the former KL Plaszow, are based on the idea of axiological education. Its meaning consists in: 1) acquiring knowledge about the difficult local history and the history of the 20th-century Holocaust by confronting the space and authentic relics of the past, and 2) referring to the independent work of students, which combines reflection on the past with self-reflection on one's own views, attitudes and dispositions. Axiological education not only stimulates historical awareness of totalitarian crimes and the memory of them in the social and moral dimension, but also - which is the most important - is an attempt to support the development of young people according to humanistic values

The mental health of a community encompasses the cultural output, emotional reference to it and a kind of wisdom that allows it to endure despite variable external circumstances. It can be perceived as the observable manifestations of the past and the degree to which its contemporaries have regulated it in accordance with a Schelerian, objective order of values or an intersubjectively elaborated order. Social work is needed in places in which social ties are becoming brittle and the consequences can be seen in the form of personal suffering, a state of alienation, and ultimately disorganisation of the picture of the world, states which we often recognise in the form of the complex phenomena of a loss of mental health. Rebuilding this health - not only by therapists - requires willingness to reflect unconditionally on one's own responsibility for harm and to search for a space for dialogue on forgiveness. 


\section{BIBLIOGRAPHY}

Ablewicz K., Pola odpowiedzialności dorosłego i dziecka. Tradycja, ponowoczesność i co dalej..., Miesięcznik Znak, 2007, 625; http://www.miesiecznik.znak.com.pl/6252007krystyna-ablewiczpola-odpowiedzialnosci-doroslego-i-dziecka-tradycja-ponowoczesnosc-ico-dalej.

Adorno T.W., Erziehung zur Mündigkeit, Suhrkamp Verlag, Frankfurt 1970.

Adorno T.W., Wychowanie po Oświęcimiu, Miesięcznik Znak, 1978, 285(3).

Alexander J.C., Eyerman, R., Giesen B., Smelser N.J., Sztompka P., Cultural Trauma and Collective Identity, University of California Press, Berkeley - Los Angeles - London 2004.

Alexander J., Znaczenia społeczne, transl. S. Burdziej, J. Gądecki, Zakład Wydawniczy Nomos, Kraków 2010.

Arendt H., Eichmann in Jerusalem. A Report on the Banality of Evil, Penguin, 2006.

Bau J., Czas zbezczeszczenia, Wydawnictwo WAM, Kraków 2006.

Bednarek M., Gawron E., Jeżowski G., Zbroja B., Zimmerer K., Kraków czas okupacji 19391945, Muzeum Historyczne Miasta Krakowa, Kraków 2010.

Bieberstein A., Zagłada Żydów w Krakowie, Wydawnictwo Literackie, Cracoviana, Kraków 1986.

Gawron E., Obóz Płaszów - część nazistowskiego planu eksploatacji gospodarczej i ludobójstwa [in:] Kraków czas okupacji 1939-1945, Eds. M. Bednarek, E. Gawron, G. Jeżowski, B. Zbroja, K. Zimmerer, Muzeum Historyczne Miasta Krakowa, Kraków 2010.

Cywiński P.M.A., Europejskie miejsca pamięci. Refleksje, [in:] Płaszów. Odkrywanie, Muzeum Historyczne Miasta Krakowa, Kraków 2016.

Duchliński P., Hołub G. (eds.), Oblicza doświadczenia aksjologicznego. Studia i rozprawy, Akademia Ignatianum, Wydawnictwo WAM, Kraków 2011.

Golka M., Pamięć społeczna i jej implant, Wydawnictwo Naukowe Scholar, Warszawa 2009.

Honneth A., The Struggle for Recognition: The Moral Grammar of Social Conflicts, transl. J. Anderson, MIT Press; 1st MIT Press ed edition, 1996.

Janusz B., Niewypowiedziane cierpienia. Międzypokoleniowy przekaz traumy, Miesięcznik Znak, 2015, 720; http:/ / www.miesiecznik.znak.com.pl/7202015bernadetta-januszniewypowiedziane-cierpienia-miedzypokoleniowy-przekaz-traumy.

Kearney R., Wybaczanie graniczne: możliwe, czy niemożliwe?, transl. M. Pancewicz-Puchalska, Studia Pfilosophica Wratislaviensia, 2010, 3.

Kiełkowski R., Zlikwidować na miejscu! Wydawnictwo Literackie, Cracoviana, Kraków 1981.

Kołodziński P., Myśli o edukacji aksjologicznej, lo2.szczecin.pl/publikacje/pawel/09.doc.

Kotarba R., Niemiecki obóz w Płaszowie 1942-1945, Instytut Pamięci Narodowej, Kraków 2009.

Kotarba R., Niemiecki obóz w Płaszowie 1942-1945. Przewodnik historyczny, Instytut Pamięci Narodowej - Komisja Ścigania Zbrodni przeciw Narodowi Polskiemu, Kraków 2016.

Macdonald S., Difficult heritage, Negotiating the Nazi Past in Nuremberg and Beyond, Routledge, London 2009.

Maliszewski K., Pedagogicznie mieszka człowiek, [in:] Pedagogika na pograniczu światów. Eseje z cyklu „Medium Mundi”, Wydawnictwo Uniwersytetu Śląskiego, Katowice 2015.

Mendel M. (ed.), Pedagogika miejsca, DSWE TWP, Wrocław 2006.

Olbrycht K., Wychowanie do wartości - w centrum aksjologicznych dylematów wspótczesnej edukacji, Paedagogia Christiana, 2012, 1(29).

Ricoeur R., Pamięć, historia, zapomnienie, transl. J. Margański, Wydawnictwo Universitas, Kraków 2006. 
Rożniatowska K., Kaszyński H., Maciejewska O., Ksztatcenie do pracy socjalnej w świetle ewaluacji Spaceru Aksjologicznego w Kobierzynie, Praca Socjalna, 2019, 3(34).

Sendyka R., Pryzma. Zrozumieć nie-miejsce pamięci (non-lieux de memoire), Teksty Drugie, 2013, 1-2.

Sendyka R., Miejsca, które straszą (afekty i nie-miejsca pamięci), Teksty Drugie: teoria literatury, krytyka, interpretacja, 2014, 1(145).

Siemianowski A., Wartości $i$ sens życia z punktu widzenia ontologicznego, [in:] Wartości dla $\dot{z}$ ycia, Ed. K. Popielski, Wydawnictwo KUL, Lublin 2008.

Wroński T., Obóz w Płaszowie - miejsce masowej eksterminacji ludności żydowskiej, polskiej i innych narodowości w latach 1942-1945, Wydawnictwo Sport i Turystyka, Warszawa 1981.

Wysok W., Wokót problematyki uwarunkowań i efektów edukacji w muzeach upamiętnienia, Zeszyty Majdanka, 2014, 26.

Żuk G., Edukacja aksjologiczna. Zarys problematyki, Wydawnictwo UMCS, Lublin 2016. 